\title{
Economic Impact of Climate Change in Port Harcourt, Nigeria
}

\author{
S. I. Efe1, V. E. Weli² \\ ${ }^{1}$ Department of Geography and Regional Panning, Delta State University, Abraka, Nigeria \\ ${ }^{2}$ Department of Geography and Environmental Management, University of Port Harcourt, Port Harcourt, Nigeria \\ Email: efesundayighovie@gmail.com, welivinezi@yahoo.com
}

Received 20 January 2015; accepted 2 March 2015; published 6 March 2015

Copyright (C) 2015 by authors and Scientific Research Publishing Inc.

This work is licensed under the Creative Commons Attribution International License (CC BY). http://creativecommons.org/licenses/by/4.0/

(c) (i) Open Access

\begin{abstract}
The study examines the economic impact of climate change. This is done through a field survey design which involves survey of marketers in Port Harcourt with the aid of archival data from Port Harcourt. Climate data were collected from the archives of Nigeria Meteorological Agency from 1950 to 2015 based on the availability of data. And data on prices and quantity of umbrella, cement, ice cream, cream, palm oil, rubber sander, cold sachet water sold, etc. were extracted from the traders' dairies from 2004 to 2014 . The data collected were presented in tables and descriptive diagrams, and analyzed with the multiple regression analysis; this was done to determine the effect of rainfall and temperature on prices of goods in the city. The results revealed an evidence of climate change in Port Harcourt with an increase of $1581 \mathrm{~mm}$ and $3^{\circ} \mathrm{C}$ for rainfall and temperature, and double rain maxima in the months of July and September. It also confirms the concept of econo-climate by establishing strong correlation between rainfall and temperature and price of goods demanded and supplied. The price and the quantity of goods demanded and supplied are significantly dependent on the amount of rainfall and temperature in the area, and as such the quantity of goods demanded and supplied negates the law of demand and supply which states that the higher the price, the higher the quantity supplied in the area. On this premise planners at the federal, state and local government levels are advised to incorporate climate mitigation and adaptation strategies in urban renewer and planning to avoid unforeseen climate disasters in our urban areas.
\end{abstract}

\section{Keywords}

Climate Change, Economic Impact, Goods, Urban Planning, Port Harcourt

\section{Introduction}

Climate change and variability affect countries’ economies and households through a variety of channels [1]. 
Rising temperatures and changes in rainfall patterns affect agricultural yields of both rainfed and irrigated crops. The unchecked rise of sea levels leads to the loss of land, landscape, and infrastructure. A higher frequency of droughts will change hydropower production, and an increase in floods can significantly increase the need for public investment in physical infrastructure [2]-[4]. These sector-level impacts will in turn affect other sectors and thus economic growth and household incomes. Depending on countries' natural conditions and economic structure, climate change affects countries differently. For example, countries that depend on rainfed agriculture, such as many in sub-Saharan Africa, are more vulnerable to an increase in climate variability, with projected large losses in their national output [5]. Countries with large delta regions, such as Vietnam, are projected to be hardest hit by rising sea levels, with strong implications for food security and the rural poor [6]. Countries that are already experiencing water stress, especially those in the Middle East and North Africa, are likely to experience additional declines in agricultural yields, resulting in negative effects on rural incomes and food security [7]. Climate change may also exacerbate climate variability and reduce agricultural production and incomes in countries that depend on annual floods such as Bangladesh or in drought-prone countries such as many in the Middle East [7] [8].

Adding up these country level effects from climate change is likely to have impacts on the global economy through changes in global supply, trade flows and commodity prices. Depending on the net importing or exporting position of countries and the net producing and consuming status of households of specific commodities affected, countries and households are likely to be affected differently by climate change. [9] [10] projected that global food prices will increase as a consequence of continued high global population growth, changing food consumption patterns, and climate change. Furthermore, continued high economic growth rates in emerging economies are likely to increase future energy costs [11]. In addition to rising energy demand, climate change mitigation policies may significantly raise energy costs, with potentially strong economic implications for developing countries [12]. For example, the Energy Information Administration (EIA) projects that oil prices may rise to US\$200 a barrel under its high-price scenario. Taking higher food and energy prices into consideration is therefore important for any climate change impact assessment at the country level. Yet, although the potentially significant impacts on world commodity price changes from climate change induced, existing country-level economic impact assessments have largely neglected this global dimension. To address this gap in the literature, this paper assesses the local economic impacts of climate change in the sub-humid tropical Niger delta city of Port Harcourt. Port Harcourt is an important case study given the city's location in a region that is consistently projected to be amongst the hardest hit by climate change.

\section{Conceptual Issues and Methods of Data Collection}

This study adopted the concept of econo-climate in explaining the economic impact of climate change. According to [13] [14] econo-climate is the economic or socioeconomic analysis of weather in an area. And this has been applied in managing the social and economic outcomes that are weather sensitive in most cities of the world [15]. Econo-climate can be use satisfactorily to resolve the following: Firstly the determination of weather attributes required by a given economic activity; their amount, frequency, and timing; Second is the assessment of the cost of economic variations arising from weather hazards in a given economic activity; and thirdly development of methods of measuring the impact of weather variation through the economic system [16]. This later aspect formed the focus of the study. The World Meteorological Organization (WMO) has stressed on the important to emphasize that information on impact of climate vagary on man's activities. Upon the above premise, the concept of econo-climate is vital to this study because it helps to understand the effect of the rainfall, temperature on the economy of Port Harcourt.

The study employs the field survey design that involves survey of traders in Port Harcourt through the use of archival data from Port Harcourt. Climate data were collected from the archives of Nigeria Meteorological Agency from 1950-2015 based on the availability of data. And data on prices of some goods (umbrella, Cement, Ice cream, Cream and Palm oil, rubber sander, cold sachet water etc were extracted from the traders' dairies from 2004-2014. These goods were selected based on the marketer's view that they are the most weather sensitive goods in the area. And the choice of 2004-2014 years is based on availability of data in the marketers dairies, continuity and consistency of records. Therefore the quantity and price of Coca Cola, baby pears, umbrella, sachet water, cement, ice cream, cream and palm oil etc. were collected and used for the study. The metropolis was stratified into 5 zones (A Ikwerre road, Afam street, B Olu-Obasanjo road, Port Horcourt Aba Express road, 
C Old Aba road, Choba/Elekahia road, D East West road, and E Trans Amadi) (see Figure 1). A trader in each of these zones with consistent documentation of sales records in dairy were selected and used for the study.

Data collected were summarized in tables and descriptive diagrams and multiple regression analysis was used to determine the effect of rainfall and temperature on prices of sachet water, baby pear umbrella, cement, ice bock, cream and palm oil etc.

\section{Results and Discussion}

The climate characteristics, quantity and price of goods sold in Port Harcourt are discussed in this section.

\subsection{Climate Characteristics}

Figure 2 showed mean annual pattern of rainfall and temperature in Port Harcourt from 1950-2015. Port Harcourt had an annual mean rainfall of $2375 \mathrm{~mm}$ that spans $1475 \mathrm{~mm}$ in 1951 to $3056 \mathrm{~mm}$ in 2012. This showed an increase of $1581 \mathrm{~mm}$ over the years. The polynomial trendline show an increase in rainfall over the years, with $0.61 \mathrm{R}^{2}$ value and shows an increase of $1581 \mathrm{~mm}$ from 1950-2015. Similarly Port Harcourt has experienced a rise of $3^{\circ} \mathrm{C}$ in temperature $\left(25^{\circ} \mathrm{C}-28^{\circ} \mathrm{C}\right)$ from $1950-2015$, with $27.2^{\circ} \mathrm{C}$ mean annual temperature distribution. The temperature polynomial trend line showed a rise in temperature with $\mathrm{R}^{2}$ value of 0.15 . The flow pattern of rainfall and temperature followed an inverse pattern, indicating that temperature decreases with an increase in rainfall in the area. This corroborated [17]-[19]. From Figure 2, the normal period of rainfall showed a u-shape, indicating a decrease in rainfall from $2693 \mathrm{~mm}$ (1950-1979) to $2316 \mathrm{~mm}$ (1980-2009), thereafter a rise to 2670 $\mathrm{mm}$ in 2010-2015, this showed that while 1950-1979 and 2010 till date are wetter epoch, 1980-2009 is the driest periods. This is an evidence of climate change in Port Harcourt with $\mathrm{R}$ value of 1 , and the polynomial trend line revealed that increase in rainfall correlated perfectly with increase in years. On the other hand from Figure 3,

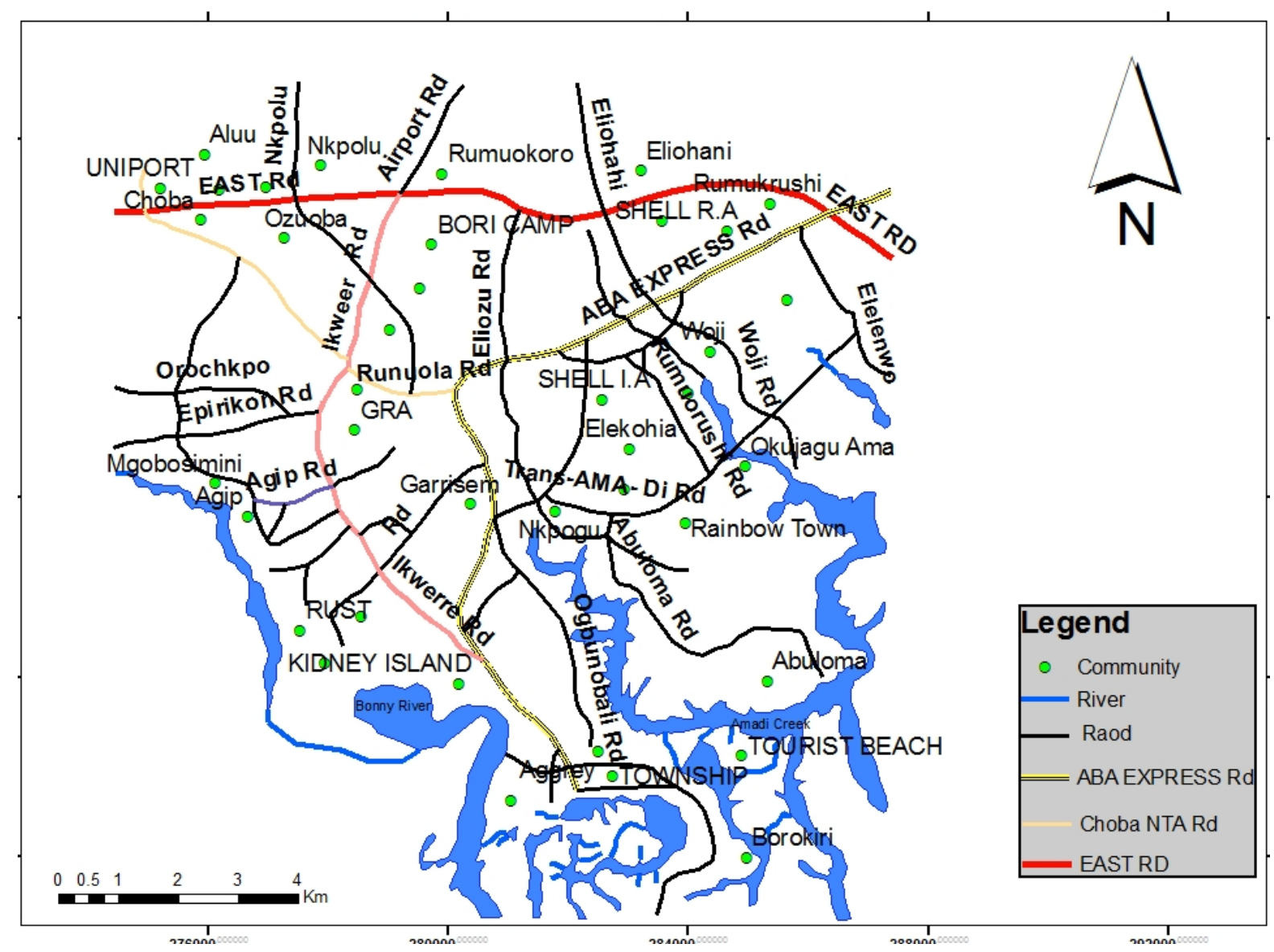

Figure 1. Port Harcourt region. 


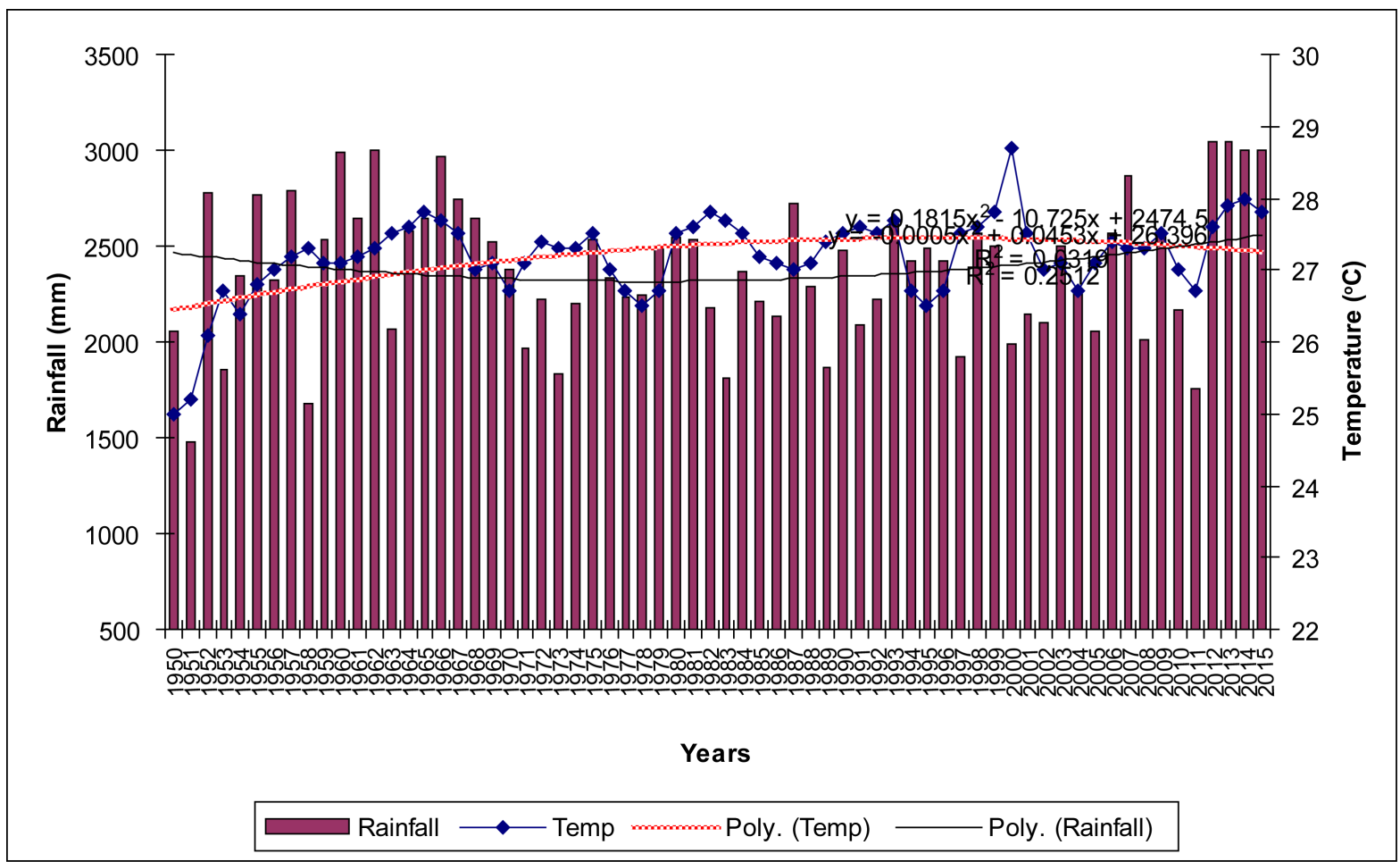

Figure 2. Annual pattern of rainfall and temperature in Port Harcourt 1950-2015.

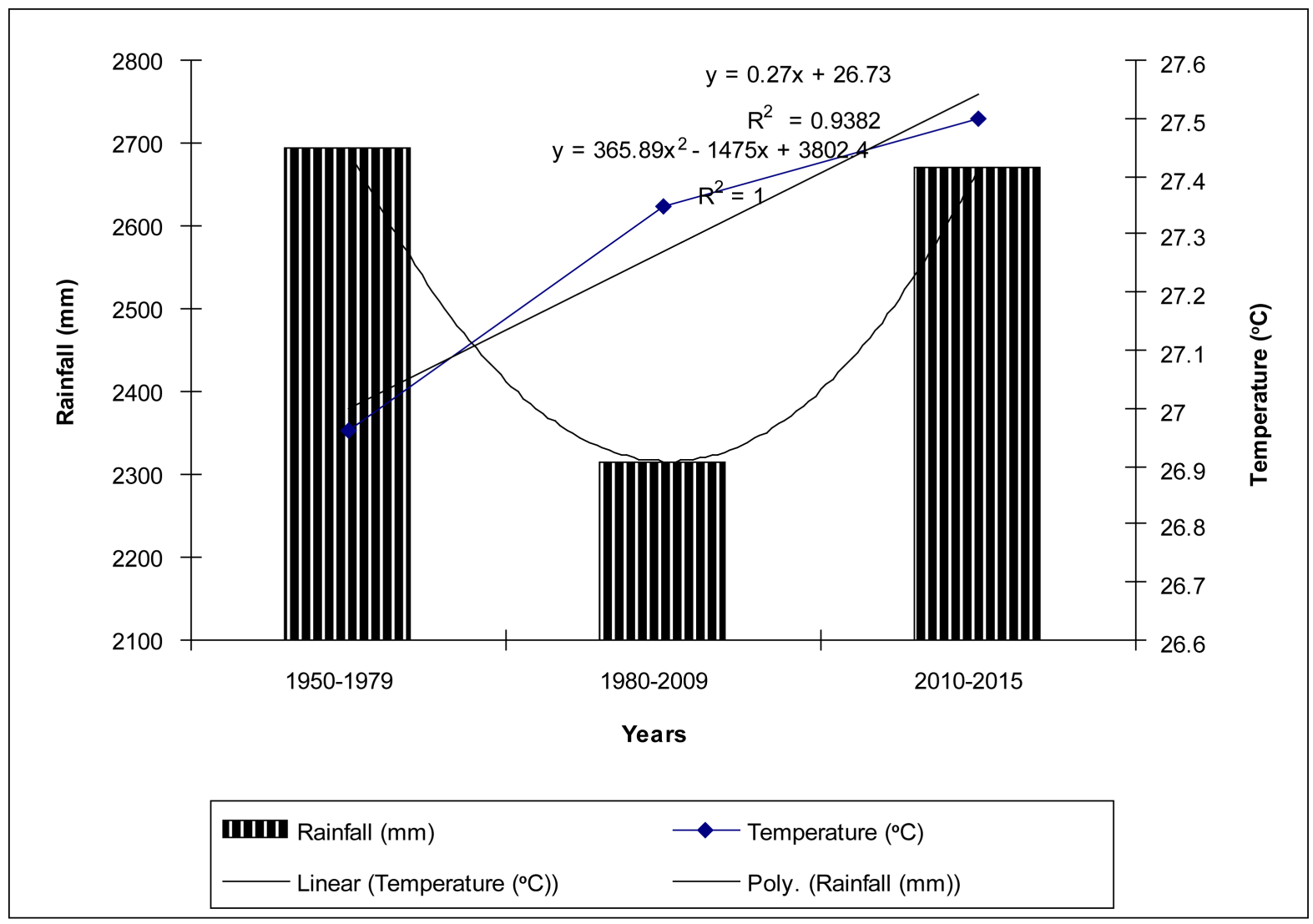

Figure 3. Rainfall normal (30 years intervals). 
there is a gradual rise in temperature from 1950-2015; this is evident with temperature values of $26.9^{\circ} \mathrm{C}, 27.4^{\circ} \mathrm{C}$ and $27.5^{\circ} \mathrm{C}$ for three epochs (1950-1979, 1980-2009 and 2010-2015). And the linear trend line showed that a rise temperature correlated strongly with increase in years with $\mathrm{R}$ value of 0.94 . This trend pattern of rainfall and temperature is an evidence of climate change in Port Harcourt. This is confirmed with a decrease of $377 \mathrm{~mm}$ in rainfall from the first epoch (1950-1979), and an increase of $354 \mathrm{~mm}$ from the second epoch (1980-2009) to the last epoch (2010-2015). This has triggered flood hazards in the area. Temperature on the other hand had a rise of $0.5^{\circ} \mathrm{C}$ from the first epoch (1950-1979) to the second epoch (1980-2009), and a rise of $0.1^{\circ} \mathrm{C}$ from the second epoch to the third epoch (2010-2015).

Table 1 the decadal rainfall pattern, which revealed that the period 1950-1959 and 1960-1969 had an increase in rainfall with $209.4 \mathrm{~mm}$ and $421.3 \mathrm{~mm}$ respectively, thereafter there is a decrease of $438.3 \mathrm{~mm}$ from 1970-1979. Nevertheless, 1980-1989 and 1990-1999 also recorded wetter periods of $19.6 \mathrm{~mm}$ to $112.9 \mathrm{~mm}$ rainfall, and a decrease of $70.3 \mathrm{~m}$ was recorded from 2000-2009. And the period 2010-2015 had an increase of $363.7 \mathrm{~mm}$ which often exacerbate ecological hazards in the area. The polynomial trend line of rainfall anomalies showed a clearer trend pattern of gradual decrease from 1950-1985, thereafter there a gradual increase in rainfall till date (see Figure 4), indicating a change in the rainfall sequence of Port Harcourt for the period 1950 till date, and this is a prove of climate change.

From Table 1 and Figure 5 the temperature pattern showed 2 epochs of $27.4^{\circ} \mathrm{C}$, and $27.5^{\circ} \mathrm{C}$ for $1950-1969$, 1980-1989, 2000-2009 and 2010 till date. This period had a temperature rise of $0.9^{\circ} \mathrm{C}, 0.4^{\circ} \mathrm{C}, 0.05^{\circ} \mathrm{C}$ and $0.14^{\circ} \mathrm{C}$ respectively, indicating a change in temperature. From Figure 4, the linear trend line of temperature anomalies showed a gradual rise in temperature from 1955 till date which showed that Port Harcourt is warmer in the last two decades than the previous years. However the first decade is cooler than other decades.

Table 2 revealed the monthly distribution of rainfall and temperature in Port Harcourt. Rainfall had $196 \mathrm{~mm}$ mean monthly distribution that spans $28 \mathrm{~mm}$ in January to $368 \mathrm{~mm}$ in September, indicating a monthly increase of $340 \mathrm{~mm}$. July and September had double rain maxima in Port Harcourt (359 and 368 respectively) which confirmed the climate characteristics of tropical equatorial climate of Koppen [20] (see Figure 5). Temperature on the other hand, had $27.1^{\circ} \mathrm{C}$ monthly mean temperature distribution, and span $26^{\circ} \mathrm{C}$ to $28.6^{\circ} \mathrm{C}$, indicating an increase of $1.5^{\circ} \mathrm{C}$ in temperature.

\begin{tabular}{|c|c|c|c|c|c|c|c|}
\hline Climate Elements & 1950-1959 & 1960-1969 & 1970-1979 & 1980-1989 & 1990-1999 & 2000-2009 & 2010-2015 \\
\hline Rainfall (mm) & 2261.52 & 2682.83 & 2244.57 & 2264.12 & 2377 & 2306.67 & 2670.4 \\
\hline Departure (mm) & 209.42 & 421.31 & -438.26 & 19.55 & 112.88 & -70.33 & 363.73 \\
\hline Temperature $\left({ }^{\circ} \mathrm{C}\right)$ & 26.48 & 27.38 & 27.02 & 27.39 & 27.31 & 27.36 & 27.5 \\
\hline Departure $\left({ }^{\circ} \mathrm{C}\right)$ & 1.48 & 0.9 & -0.36 & 0.37 & -0.08 & 0.05 & 0.14 \\
\hline 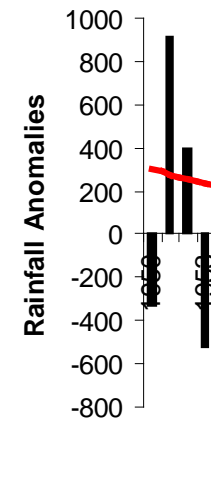 & 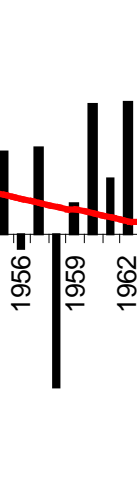 & 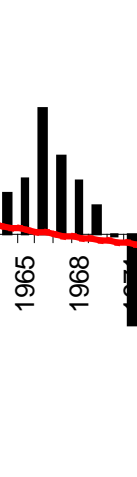 & 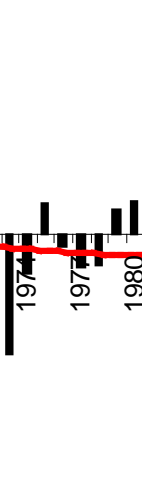 & ears & Љু & |ू্స & 赵 \\
\hline & & & Anomalies & -Poly. (A & omalies) & & \\
\hline
\end{tabular}

Figure 4. Rainfall anomalies 1950-2015. 


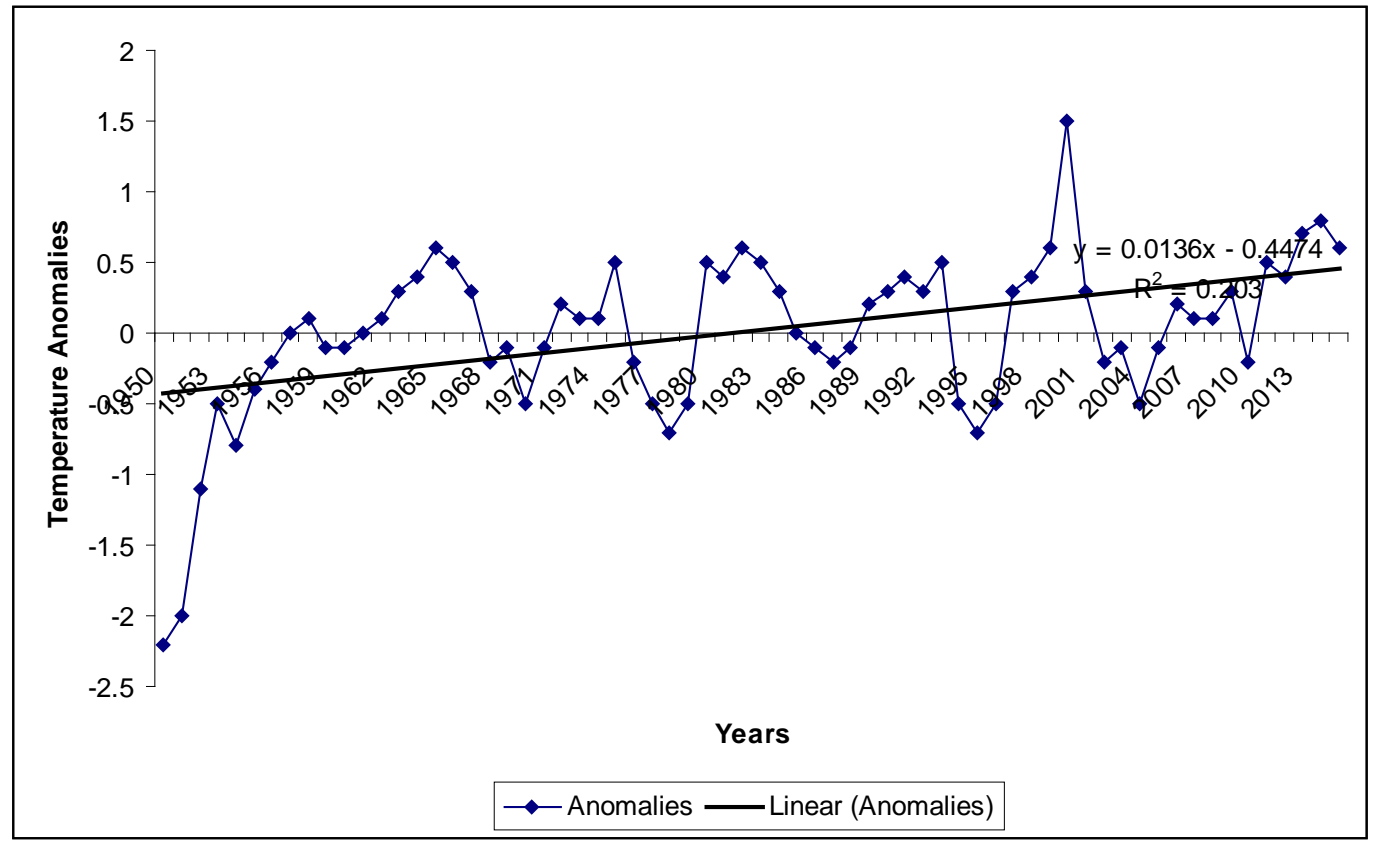

Figure 5. Temperature anomalies 1950-2015.

Table 2. Seasonal distribution of climate characteristics 1950-2012.

\begin{tabular}{ccccccccccccc}
\hline Months & Jan & Feb & Mar & Apr & May & Jun & Jul & Aug & Sept & Oct & Nov & Dec \\
\hline Rainfall $(\mathrm{mm})$ & 28 & 64 & 130 & 174 & 255 & 273 & 359 & 306 & 368 & 268 & 100 & 30 \\
Temp ${ }^{\circ} \mathrm{C}$ & 27 & 27.4 & 28.6 & 28.3 & 27.6 & 26.8 & 26.1 & 26.2 & 26 & 26.7 & 27.1 & 27.2 \\
\hline
\end{tabular}

There is double recession or fall in temperature in July $\left(26.1^{\circ} \mathrm{C}\right)$ and September $\left(26^{\circ} \mathrm{C}\right)$ (see Figure 6). This showed that monthly temperature decreases with increasing rainfall. However the linear trend line revealed a gradual rise in temperature from 1950 till date (see Figure 6).

\subsection{Quantity and Price of Good Sold}

The quantity of goods sold in Port Harcourt from 2004-214 is presented in Table 3. Generally the quantities of goods sold increase with increase in years. This could be ascribed to increase in the population of Port Harcourt being an oil city.

These quantities are: sachet water span 4181 - 5687 bags (2004) with a mean of 4675 bags, Palm oil recorded 1001 to 1670/per 20 litres (2004-2014) and a 1194/20litres mean value, Okra 718 baskets mean and it range from 550 - 980 baskets, cement had a 4754 bags mean value that ranges from 3480 - 6698 bags. Others are Coca Cola span 470 - 1098 with mean value of 738 bags; Umbrella had a mean of 722 that span 586 - 932; Rubber shoes recorded 276 mean and ranges from 201 - 420; Ice cream had a mean of 649/pe dozen and range 460 920/dozen; mentholator had 2106 mean value and varies from 1535 - 2610; and Baby Pears lotion/oil span 367 854 with a mean value of 519 (see Table 3).

Generally fro Table 4, the quantity of goods sold followed the climate of the area. For instance, generally the goods increased in months with lower rainfall with September being the month with lowest sales (110 bags) and January had the highest sales (630 bags), and there is double decrease in quantity of sachet water sold in July and Septembers over the years. Palm oil, cement and Coka Cola followed same pattern with sachet water of reduction in sales in the months of July and September. This showed that as rainfall increases/weather become cooler, the demand for sachet water, palm oil, cement, Coka Cola, ice cream, baby pears reduces. However the quantity of okra, umbrella, rubber shoes and rob/mentholator sold increased with increase in rainfall and low temperature, with double sales maxima July and September just like those of rainfall (see Table 4 and Figure 5). 


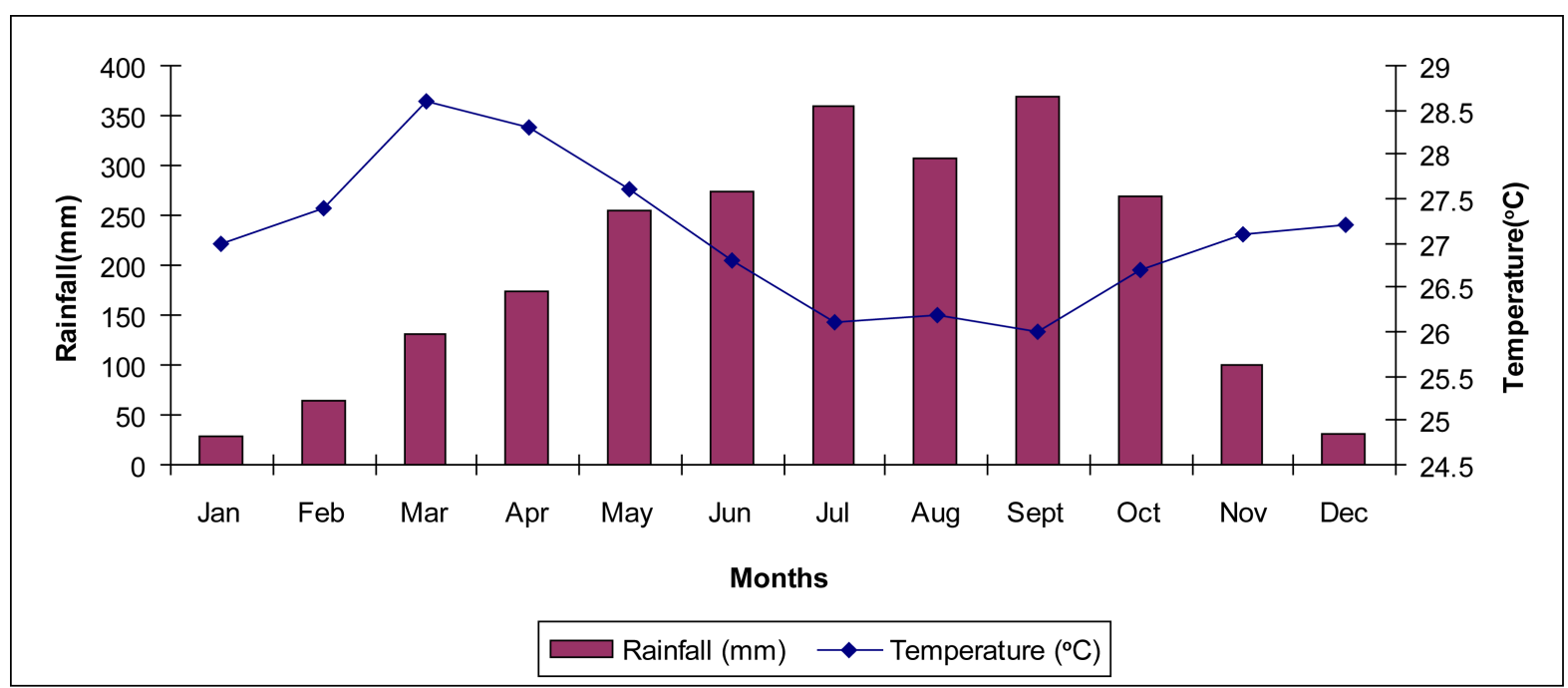

Figure 6. Mean monthly pattern of rainfall and temperature 1950-2012.

Table 3. Mean annual quantity of item sold per trader.

\begin{tabular}{|c|c|c|c|c|c|c|c|c|c|c|}
\hline Months & $\begin{array}{c}\text { Sarchet } \\
\text { water/bag }\end{array}$ & $\begin{array}{l}\text { Palm oil/ } \\
20 \text { litres }\end{array}$ & Okra/basket & Cement & $\begin{array}{c}\text { Coca Cola/ } \\
\text { creates }\end{array}$ & Umbrella & $\begin{array}{l}\text { Rubber } \\
\text { shoe }\end{array}$ & $\begin{array}{l}\text { Ice cream/ } \\
\text { pack of } 12\end{array}$ & $\begin{array}{c}\text { Rob/ } \\
\text { mentholator }\end{array}$ & $\begin{array}{l}\text { Pears } \\
\text { lotion }\end{array}$ \\
\hline 2004 & 4182 & 1001 & 550 & 3480 & 479 & 586 & 201 & 460 & 1535 & 367 \\
\hline 2005 & 4198 & 1067 & 590 & 3500 & 502 & 590 & 205 & 495 & 1780 & 386 \\
\hline 2006 & 4210 & 1088 & 603 & 3500 & 530 & 610 & 205 & 503 & 1956 & 403 \\
\hline 2007 & 4256 & 1100 & 610 & 3689 & 560 & 638 & 203 & 540 & 2000 & 432 \\
\hline 2008 & 4300 & 1100 & 630 & 3860 & 640 & 683 & 231 & 506 & 2002 & 450 \\
\hline 2009 & 4367 & 1158 & 678 & 4021 & 692 & 705 & 275 & 584 & 2000 & 472 \\
\hline 2010 & 4389 & 1164 & 705 & 4785 & 768 & 735 & 300 & 650 & 2140 & 498 \\
\hline 2011 & 5056 & 1200 & 780 & 5758 & 852 & 766 & 310 & 720 & 2200 & 520 \\
\hline 2012 & 5382 & 1270 & 850 & 6488 & 979 & 889 & 331 & 869 & 2356 & 579 \\
\hline 2013 & 5400 & 1287 & 920 & 6510 & 1020 & 810 & 356 & 896 & 2589 & 751 \\
\hline 2014 & 5687 & 1670 & 980 & 6698 & 1098 & 932 & 420 & 920 & 2610 & 854 \\
\hline Mean & 4675 & 1191 & 718 & 4754 & 738 & 722 & 276 & 649 & 2106 & 519 \\
\hline
\end{tabular}

Source: sales dairies of major dealers 2004-2014.

Table 4. Mean seasonal quantity of item sold per trader.

\begin{tabular}{|c|c|c|c|c|c|c|c|c|c|c|}
\hline Months & $\begin{array}{c}\text { Searchet } \\
\text { water/bag }\end{array}$ & $\begin{array}{l}\text { Palm oil/ } \\
20 \text { litres }\end{array}$ & $\begin{array}{l}\text { Okra/ } \\
\text { basket }\end{array}$ & Cement & $\begin{array}{c}\text { Coca Cola/ } \\
\text { creates }\end{array}$ & Umbrella & $\begin{array}{l}\text { Rubber } \\
\text { Shoe }\end{array}$ & $\begin{array}{l}\text { Ice cream/ } \\
\text { pack of } 12\end{array}$ & $\begin{array}{c}\text { Rob/ } \\
\text { mentholator }\end{array}$ & $\begin{array}{l}\text { Pears } \\
\text { lotion }\end{array}$ \\
\hline Jan & 660 & 120 & 32 & 750 & 93 & 12 & 15 & 84 & 220 & 67 \\
\hline Feb & 630 & 120 & 58 & 620 & 86 & 15 & 17 & 90 & 165 & 65 \\
\hline March & 630 & 116 & 68 & 730 & 82 & 18 & 20 & 87 & 165 & 50 \\
\hline April & 560 & 109 & 74 & 674 & 79 & 20 & 27 & 88 & 156 & 47 \\
\hline May & 535 & 93 & 74 & 600 & 71 & 58 & 30 & 75 & 168 & 40 \\
\hline June & 320 & 88 & 78 & 262 & 60 & 63 & 35 & 73 & 180 & 33 \\
\hline July & 156 & 87 & 100 & 85 & 55 & 130 & 50 & 32 & 260 & 32 \\
\hline Aug & 386 & 90 & 95 & 120 & 67 & 106 & 42 & 58 & 245 & 39 \\
\hline Sept & 110 & 82 & 100 & 67 & 50 & 185 & 56 & 30 & 265 & 29 \\
\hline Oct & 367 & 110 & 54 & 682 & 85 & 65 & 16 & 76 & 167 & 37 \\
\hline Nov & 420 & 125 & 33 & 830 & 98 & 45 & 13 & 87 & 175 & 66 \\
\hline Dec & 608 & 130 & 34 & 858 & 152 & 15 & 10 & 89 & 200 & 69 \\
\hline Mean & 5382 & 1270 & 800 & 6278 & 978 & 732 & 331 & 869 & 2366 & 574 \\
\hline
\end{tabular}

Source: sales dairies of major dealers. 
However, rob and mentholator sales is high in December and January because of harmatan season experienced. The increase in quantity of sachet water, rob/mentholator, palm oil and cement sold all through the year and season according to the inhabitants and the traders is due to the fact that these products used throughout the seasons of the year, be cold and warm season. This corroborated [16].

Table 5 showed the price of goods sold in Port Harcourt. Generally prices of all the goods increases over the years. The price of these goods increases as the quantity of these goods increases (see Table 4 and Table 5). However the price changes with the season of the years (see Table 6). For instance the price of umbrella, rubber sander, pears oil and rob/mentholator increases with increase in rainfall, and falls with increase in temperature (see Table 6 and Figure 6). On the other hand, the prices of cement, ice cream, cold sachet water, Okra and Coca Cola decreases with increase in rainfall, and rises with increase in temperature (see Table 6 and Figure 6). These results corroborated those of [16] in the city of Warri.

Table 5. Prices of some goods in Port Harcourt.

\begin{tabular}{cccccccccc}
\hline Years & Oil palm & Okro & Corn & Cement & Umbrella & Sharp sand & Zinc & Nails & Coca-Cola drink \\
\hline 2004 & 2500 & 13,000 & 2700 & 1400 & 200 & 1500 & 7600 & 680 & 850 \\
2005 & 2500 & 14,000 & 2500 & 1500 & 250 & 2000 & 7600 & 700 & 850 \\
2006 & 3000 & 15,500 & 2800 & 1600 & 300 & 2000 & 7600 & 700 & 980 \\
2007 & 3500 & 17,000 & 2800 & 1650 & 300 & 2000 & 7900 & 750 & 980 \\
2008 & 4000 & 18,000 & 3000 & 1550 & 350 & 3500 & 8050 & 790 & 950 \\
2009 & 6000 & 19,000 & 2800 & 1700 & 350 & 3500 & 8050 & 790 & 950 \\
2010 & 7500 & 19,500 & 3000 & 1650 & 400 & 3000 & 8200 & 790 & 1000 \\
2011 & 6000 & 20,000 & 3200 & 1750 & 400 & 3000 & 8300 & 900 & 1000 \\
2012 & 6500 & 20,000 & 3500 & 1800 & 450 & 3000 & 8350 & 990 & 1000 \\
2013 & 6500 & 20,000 & 7000 & 1850 & 500 & 3000 & 8300 & 835 & 1000 \\
2014 & 6700 & 20,300 & 9000 & 1900 & 600 & 3200 & 8500 & 850 & 1050 \\
2015 & 7200 & 21,000 & 10,000 & 2000 & 650 & 3700 & 8620 & 900 & 1050 \\
Mean & 5158 & 18,108 & 4358 & 1696 & 396 & 2783 & 8261 & 806 & 972 \\
\hline
\end{tabular}

Table 6. Mean seasonal price of goods sold per trader $(\mathrm{N})$.

\begin{tabular}{ccccccccccc}
\hline Months & $\begin{array}{c}\text { Searchet } \\
\text { water/bag }\end{array}$ & $\begin{array}{c}\text { Palm oil/ } \\
20 \text { litres }\end{array}$ & $\begin{array}{c}\text { Okra/ } \\
\text { basket }\end{array}$ & Cement & $\begin{array}{c}\text { Coca Cola/ } \\
\text { creates }\end{array}$ & Umbrella & $\begin{array}{c}\text { Rubber } \\
\text { sanderr }\end{array}$ & $\begin{array}{c}\text { Ice cream/ } \\
\text { pack of } 12\end{array}$ & $\begin{array}{c}\text { Rob/ } \\
\text { mentholator }\end{array}$ & $\begin{array}{c}\text { Pears } \\
\text { lotion/oil }\end{array}$ \\
\hline Jan & 120 & 4500 & 21,000 & 1850 & 1000 & 200 & 150 & 240 & 125 & 250 \\
Feb & 110 & 4500 & 21,100 & 1850 & 980 & 210 & 150 & 240 & 125 & 250 \\
March & 120 & 4800 & 14,500 & 1600 & 980 & 300 & 150 & 240 & 130 & 250 \\
April & 120 & 5500 & 15,500 & 1650 & 980 & 300 & 155 & 240 & 140 & 250 \\
May & 110 & 5700 & 17,000 & 1550 & 950 & 310 & 155 & 240 & 140 & 250 \\
June & 100 & 5700 & 17,500 & 1700 & 950 & 360 & 155 & 220 & 145 & 250 \\
July & 100 & 6650 & 190,00 & 1650 & 850 & 610 & 220 & 200 & 160 & 255 \\
Aug & 100 & 6500 & 19,500 & 1750 & 850 & 400 & 220 & 200 & 160 & 255 \\
Sept & 100 & 7400 & 14,500 & 1500 & 850 & 670 & 250 & 200 & 167 & 300 \\
Oct & 100 & 4550 & 20,000 & 1850 & 950 & 455 & 150 & 240 & 160 & 250 \\
Nov & 110 & 4600 & 21,800 & 1950 & 1000 & 269 & 160 & 240 & 150 & 250 \\
Dec & 120 & 4700 & 21,950 & 2000 & 1050 & 250 & 150 & 240 & 150 & 250 \\
Mean & 109.17 & 5425 & 18612.5 & 1741.67 & 949.17 & 361.17 & 172.08 & 228.33 & 146 & 255 \\
\hline
\end{tabular}

Source: sales dairies of major dealers. 
Tables 7-10 showed the results of the regression analyses performed to establish the effects of rainfall and temperature on goods in Port Harcourt. Table 7 revealed 0.996 correlation value that rainfall had on the prices of Cement, Ice cream, cold sachet water, okra, Coca Cola, umbrella, rubber sander, baby pears oil cream, palm oil, and rob/mentholator. This showed that rainfall contribute 99\% to the market price of these goods in Port Harcourt. Their individual standardized beta coefficients in Table 8, indicate correlation coefficient values of $0.77,0.72,0.51,0.66$ and 0.67 respectively for umbrella, rubber sander, baby pears oil cream, palm oil, and $\mathrm{rob} /$ mentholator which showed that the prices of these goods increases with increase in rainfall. This confirmed the concept of econo-climate by establishing the above strong positive correlation between rainfall and temperature and price of goods demanded and supplied. The prices of cement, ice cream, cold sachet water, okra, and Coca Cola drinks had an inverse relationship $(-0.51,-0.55,-0.63,-0.61$ and -0.66 respectively for these items), which showed that as rainfall increases, there is a correspondence fall in prices of these items. However the $t$ value 9.614 is significantly at $\mathrm{P}<0.05$ significant level (see Table 8). Based on this, the study revealed that the prices of cement, ice cream, cold sachet water, okra, Coca Cola, umbrella, rubber sander, baby pears oil cream, palm oil, and rob/mentholator were significantly dependent on rainfall amount experienced over the season and year.

From Table 9, correlation value that temperature had on the prices of cement, ice cream, cold sachet water, okra, Coca Cola, umbrella, rubber sander, baby pears oil cream, palm oil, and rob/mentholator is 0.99 . And this indicates that temperature contributed $98 \%$ to the market price of goods in Port Harcourt. However, the

Table 7. Regression model summary of the relationship between rainfall and price of goods.

\begin{tabular}{ccccc}
\hline Model & $\mathrm{R}$ & R Square & Adjusted R Square & Std. Error of the Estimate \\
\hline 1 & $0.996^{(\mathrm{a})}$ & 0992.000 & 0.896 & 7.42587 \\
\hline
\end{tabular}

(a)Predictors: (constant), pears, sachet, okra, rob, palm oil, umbrella, Coca Cola, cement, ice cream, rubber sander.

Table 8. Standardize beta coefficients ${ }^{(a)}$ explaining the effects of rainfall on price of goods.

\begin{tabular}{|c|c|c|c|c|c|c|}
\hline \multirow{2}{*}{ Model } & & \multicolumn{2}{|c|}{ Unstandardized Coefficients } & \multirow{2}{*}{$\begin{array}{c}\text { Standardized Coefficients } \\
\text { Beta }\end{array}$} & \multirow{2}{*}{$\begin{array}{l}\mathrm{t} \\
\mathrm{B}\end{array}$} & \multirow{2}{*}{$\begin{array}{c}\text { Sig. } \\
\text { Std. Error }\end{array}$} \\
\hline & & B & Std. Error & & & \\
\hline \multirow{11}{*}{1} & (Constant) & 1485.951 & 154.565 & & 9.614 & 0.066 \\
\hline & Sachet & -2.096 & 0.975 & -0.652 & -2.150 & 0.277 \\
\hline & Palm oil & 0.046 & 0.014 & 0.664 & 3.209 & 0.192 \\
\hline & Okra & 0.000 & 0.003 & -0.609 & 0.145 & 0.909 \\
\hline & Cement & -0.164 & 0.093 & -0.511 & -1.776 & 0.326 \\
\hline & Coca Cola & -1.241 & 0.362 & -0.659 & -3.428 & 0.181 \\
\hline & Umbrella & 0.140 & 0.057 & 0.769 & 2.442 & 0.247 \\
\hline & Rubber sander & -2.503 & 0.660 & 0.723 & -3.791 & 0.164 \\
\hline & Ice cream & 0.387 & 0.838 & -0.554 & 0.462 & 0.725 \\
\hline & Rob & 3.163 & 0.466 & 0.666 & 6.792 & 0.093 \\
\hline & Pears & -0.079 & 0.562 & 0.509 & -0.140 & 0.911 \\
\hline
\end{tabular}

(a) Dependent variable: rainfall.

Table 9. Regression model summary the relationship between temperature and price of goods.

\begin{tabular}{|c|c|c|c|c|}
\hline Model & $\mathrm{R}$ & R Square & Adjusted R Square & Std. Error of the Estimate \\
\hline 1 & $0.990^{(\mathrm{a})}$ & 0.980 & 0.777 & 0.38030 \\
\hline
\end{tabular}

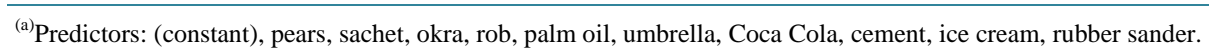


Table 10. Standardize beta coefficients ${ }^{(a)}$ explaining the effects of temperature on price of goods.

\begin{tabular}{|c|c|c|c|c|c|c|}
\hline \multirow{2}{*}{ Model } & & \multicolumn{2}{|c|}{ Unstandardized Coefficients } & \multirow{2}{*}{$\begin{array}{c}\text { Standardized Coefficients } \\
\text { Beta }\end{array}$} & \multirow{2}{*}{$\begin{array}{l}\mathrm{t} \\
\mathrm{B}\end{array}$} & \multirow{2}{*}{$\begin{array}{c}\text { Sig. } \\
\text { Std. Errol }\end{array}$} \\
\hline & & B & Std. Error & & & \\
\hline \multirow{11}{*}{1} & (Constant) & 24.902 & 7.916 & & 3.146 & 0.196 \\
\hline & Sachet & 0.001 & 0.050 & 0.510 & 0.017 & 0.989 \\
\hline & Palm oil & 0.000 & 0.001 & -0.499 & -0.312 & 0.808 \\
\hline & Okra & 0.000 & 0.000 & 0.686 & -1.231 & 0.434 \\
\hline & Cement & -0.001 & 0.005 & 0.555 & -0.165 & 0.896 \\
\hline & Coca cola & $-3.60 \mathrm{E}-005$ & 0.019 & 0.603 & -0.002 & 0.999 \\
\hline & Umbrella & 0.000 & 0.003 & -0.584 & 0.154 & 0.903 \\
\hline & Rubber sander & 0.010 & 0.034 & 0.464 & 0.308 & 0.810 \\
\hline & Ice cream & 0.051 & 0.043 & 1.094 & 1.187 & 0.446 \\
\hline & Rob & 0.006 & 0.024 & -0.414 & 0.267 & 0.834 \\
\hline & Pears & -0.025 & 0.029 & -0.444 & -0.867 & 0.545 \\
\hline
\end{tabular}

${ }^{(a)}$ Dependent variable: temp.

standardized beta coefficients in Table 10, revealed a correlation coefficient values of $-0.58,-0.46,0.44,-0.50$, -0.41 , respectively for umbrella, rubber sander, baby pears oil cream, palm oil, and rob/mentholator. This is an inverse relationship which showed that the prices of these goods reduce with increase in temperature. The prices of cement, ice cream, cold sachet water, okra, and Coca Cola drinks had an inverse relationship (0.55, 1.09, 0.50, 0.69 and 0.60 respectively for these items), which showed that as rainfall increases, there is a correspondence increase in prices of these items. However the $\mathrm{t}$ value 3.15 is significantly at $\mathrm{P}<0.05$ significant level (see Table 10). Based on this, the study revealed that the prices of cement, ice cream, cold sachet water, okra, Coca Cola, umbrella, rubber sander, baby pears oil cream, palm oil, and rob/mentholator were significantly dependent on temperature experienced over the season and year.

From Figure 2, the period 2010-2015 had an increase of $363.7 \mathrm{~m}$ which often exacerbate ecological hazards (flood, acid rain, soil erosion etc.) in the area [21] [22]. And one of such impact is the 2012 flood episode. From Table 11, before the inundation began, bag of garri is sold for N9000, and 128 bags of garri were demanded and supplied. But as rainfall increases, inundation level rise to cover most cassava farmlands in the rural area of Port Harcourt, as such quantity demanded increases with decrease in supply of garri to Port Harcourt. Thus demand outweigh supply, this is evident from only $70 \%$ and $28 \%$ bags of garri demanded that was supplied at the second and third months respectively. This confirmed the law of demand in economics. But the quantity supplied reduces as prices increases, and thus negate supply law in economics. But as prices of garri increases as a result of the flood, the quantity demanded also increases in defilement of the law of demand and supply. Thus prices are directionary proportionate to quantity demanded because the flood hazards has forced many inhabitants of the neighboring areas to relocate to join their relative and settlement camps in Port Harcourt. The price became expensive that most middle class residents can no longer afford it. This has exacerbated hunger and food insecurity in the area because it is only $45 \%$ of their demand that were met.

Table 12 revealed that the quantity demanded and supplied decreases with increase in price of fishes. For instance at N200, 150 and 63 fishes were demanded and supplied. And at N1000, 6 and 2 fishes were supplied. While the quantity of fishes demanded comply with the demand law in economics which states that the higher the price the lower the quantity demanded (see Figure 7(a) and Figure 7(b)), the quantity supplied is a negation from the law of demand and supply in economics, that states that the higher the price the higher the quantity supplied (see Figure 7(a) and Figure 7(b)). The abnormal supply curve is precipitated by increase in rainfall that occasioned high inundation level. This rose to overflow the rivers and fish ponds in Port Harcourt and environs, and causes most the fishes to escape along with the flood water. The quantity demanded also outweigh quantity supplied, during this period, it is only $55 \%$ of the quantity demanded that were supplied, and the percentage supplied decreases from 63\% at N200 to 40\% at N1000 (see Table 12 and Figure 7(a)). 
Table 11. Price and quantity (Qt) of garri during 2012 flood.

\begin{tabular}{ccccc}
\hline Months & Price & Mean Qt Demanded & Mean Qt Supplied & \% Supplied \\
\hline Before flood & 9000 & 128 & 128 & 100 \\
$1^{\text {st }}$ month & 15,000 & 129 & 90 & 70 \\
$2^{\text {nd }}$ month & 18,000 & 360 & 102 & 28 \\
& & 517 & 320 & 45 \\
\hline
\end{tabular}

Table 12. Price and quantity (Qt) of fishes during 2012 flood per trader.

\begin{tabular}{cccc}
\hline Price $(\mathrm{N})$ & Mean Qt Demanded & Mean Qt Supplied & \% Supplied \\
\hline 200 & 150 & 94 & 63 \\
400 & 100 & 53 & 53 \\
600 & 60 & 29 & 48 \\
800 & 20 & 8 & 40 \\
1000 & 6 & 2 & 33 \\
Total & 336 & 186 & 55.4 \\
\hline
\end{tabular}

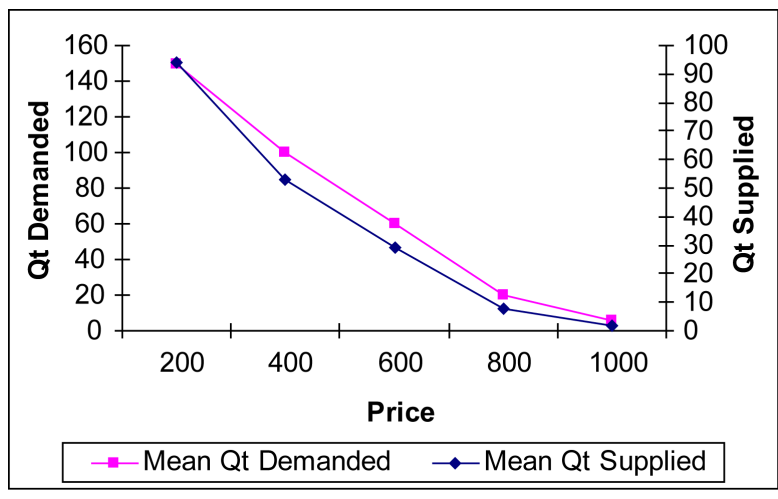

(a)

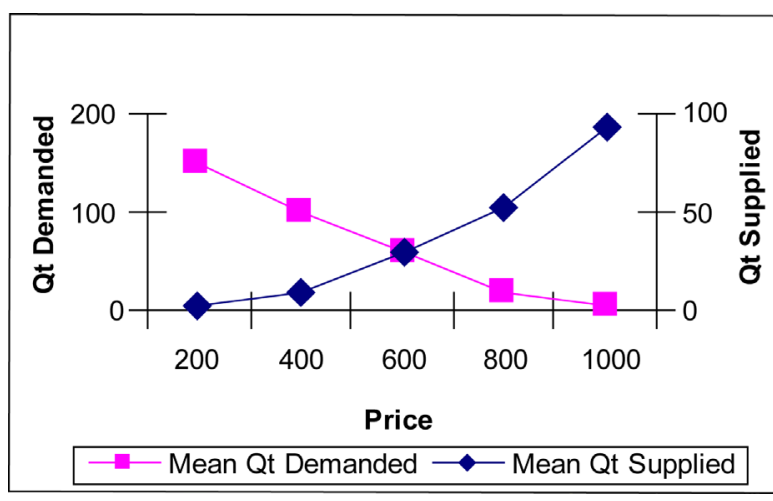

(b)

Figure 7. (a) Demand and supply of fish occasioned by inundation; (b) Normal demand and supply of fish.

Figure 7(a) showed that the quantity of fishes demanded and supplied followed same pattern that reduces with increase in price. This is a negation from the normal demand and supply of fishes before the flood (see Figure 7(b)). Another factor that account for the abysmal supplied is the occurrence of acid rain in the region. The occurrence of acid rain has resulted in the lost of fish species and reduced quantity of fish caught by farmers [23].

\section{Conclusion}

The study has demonstrated that the economy of Port Harcourt is dependent on climate change. It revealed that Port Harcourt experiences rainfall of $2375 \mathrm{~mm}$ and temperature of $27.2^{\circ} \mathrm{C}$ with an increase of $1581 \mathrm{~mm}$ and $3^{\circ} \mathrm{C}$ for rainfall and temperature respectively from 1950 to 2015. This increase in rainfall and temperature indicates an evidence of climate change which precipitated other ecological hazards like urban heat island, the 2012 flood, and acid rain in the area and thus impacted negatively on the economy of Port Harcourt. It is showed that the prices of umbrella, rubber sander, baby pears oil cream, palm oil, and rob/mentholator increase with increasing rainfall; cement, ice cream, cold sachet water, okro and Coca Cola prices on the other hand reduce with increase in rainfall. The prices of these good are also significantly dependent on the temperature experienced over the season and year, and thus it is also revealed that the quantities of garri and fishes demanded and supplied de- 
crease with increase in price which negates the law of supply, which states that the higher the price, the higher the quantity supplied. Hence the prices is directly proportionate to quantity demanded, because the increased rainfall leads to flood hazards which force many inhabitants of the neighboring areas to relocate to join their relatives and settlement camps in Port Harcourt. It is therefore recommended that economic, environmental and urban planners should incorporate climate adaptation option in their planning in order to protect their goods against climate disasters, as well as implement the urban developmental laws in the area.

\section{References}

[1] Breisinger, C., Zhu, T., Al Riffai, P., Nelson, G., Robertson, R., Funes, J. and Verner, D. (2011) Global and Local Economic Impacts of Climate Change in Syria and Options for Adaptation IFPRI Discussion Paper 01091. Development Strategy and Governance Division, International Food Policy Research Institute. Washington DC.

[2] Stern, N. (2006) Review on the Economics of Climate Change. http://www.sternreview.org.uk

[3] World Bank (2007) The Impact of Sea Level Rise on Developing Countries: A Comparative Analysis. World Bank Policy Research Working Paper WPS4136, World Bank, Washington DC.

[4] Garnaut, R. (2008) The Garnaut Climate Change Review: Final Report. www.garnautreview.org.au/index.htm

[5] Thurlow, J., Zhu, T. and Diao, X. (2009) The Impact of Climate Variability and Change on Economic Growth and Poverty in Zambia. IFPRI Discussion Paper 00890, International Food Policy Research Institute, Washington DC.

[6] Yu, B., You, L. and Fan, S. (2010) Toward a Typology of Food Security in Developing Countries. IFPRI Discussion Paper 00945, International Food Policy Research Institute, Washington DC.

[7] Breisinger, C., van Rheenen, T., Ringler, C., Pratt, A.N., Minot, N., Aragon, C., Yu, B., Ecker, O. and Zhu, T. (2010) Food Security and Economic Development in the Middle East and North Africa: Current State and Future Perspectives. IFPRI Discussion Paper 00985, International Food Policy Research Institute, Washington DC.

[8] Yu, W., Thurlow, J., Alam, M., Hassan, A., Khan, A.S., Ruane, A., Rosenzweig, C., et al. (2010) Climate Change Risks and Food Security in Bangladesh. EarthScan, London.

[9] Nelson, G.C., Rosegrant, M.W., Koo, J., Robertson, R., Sulser, T., Zhu, T., et al. (2009) Climate Change: Impact on Agriculture and Costs of Adaptation. Food Policy Report, IFPRI, Washington DC.

[10] Efe, S.I. (2009) Climate Change and Food Security in African: Delta State Nigeria Experience. Anyadike, R.N.C., Madu, L.A. and Ajaero, Eds., Conference Proceeding on Climate Change and the Nigerian Environment, Nsukka, 29 June-2 July 2009, 105-126.

[11] IEA (2010) World Energy Outlook 2010. IEA, Paris.

[12] DOE (UK Department of Energy and Climate Change) (2010) Estimated Impacts of Energy and Climate Change Policies on Energy Prices and Bills. www.decc.gov.uk

[13] Maunder, W.J. (1970) The Values of Weather. Methen, London.

[14] Maunder, W.J. (1972) The Formulation of Weather Indices for Use in Climatic-Economic Studies a New Zealand Example. New Zealand Geographers, 28, 130-150. http://dx.doi.org/10.1111/j.1745-7939.1972.tb01179.x

[15] Ayoade, J.O. (2004) Climate Change: A Synopsis of Its Nature, Causes, Effects and Management. Vantage Publishers Ltd., Ibadan.

[16] Efe, S.I. and Ojoh, C. (2011) Climate Variability and Commercial Activities in Warri Metropolis, Nigeria. Journal of Social and Management Sciences, 6, 61-68.

[17] Efe, S.I. and Ojoh, C. (2013) Climate Variability and Malaria Prevalence in Warri Metropolis. Atmospheric and Climate Science, 3, 132-140.

[18] Efe, S.I. and Ojoh, C.O. (2013) Spatial Distribution of Malaria in Warri Metropolis. Open Journal of Epidemiology, 3, 118-124. http://dx.doi.org/10.4236/ojepi.2013.33018

[19] Weli, V.E. and Efe, S.I. (2015) Climate and Epidemiology of Malaria in Port Harcourt Region, Nigeria. AJCC, in Press.

[20] Efe, S.I. (2006) Regionalisation of Nigeria Climate: A Recent Approach. The Nigerian Academic Forum, 11, 32-39.

[21] Efe, S.I. (2011) Climate Change and Flood Hazards in the Niger Delta Region of Nigeria. Niger Delta Research Digest, 5, 43-60.

[22] Elenwo, I. and Efe, S.I. (2014) Flood Problem in Port Harcourt, Nigeria. International Journal of Environmental Engineering and Natural Resources, 1, 97-107.

[23] Efe, S.I. (2012) Climate Change and Environmental Degradation: The Case of Acid Rain in Nigeria. In: IIiya, M.A. and Dankani, I.M., Eds., Climate Change and Sustainable Development in Nigeria, Association of Nigerian Geographers (ANG), 199-228. 